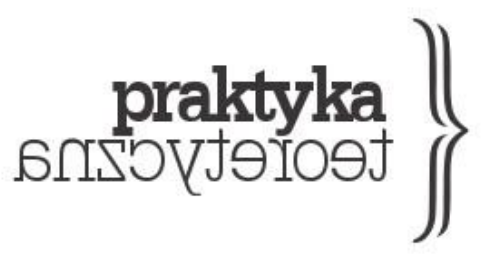

\title{
OD WALKI KLAS DO ZDERZENIA CYWILIZACJI. GEOPOLITYKA I EKONOMIA POLITYCZNA ISLAMOFOBII
}

\author{
PRZEMYSŁAW WIELGOSZ
}

\begin{abstract}
Abstrakt: Artykul jest próbą zarysowania ekonomicznych i politycznych ram oraz historycznego procesu formowania się współczesnych postaci islamofobii. Autor wskazuje, że odbywało się to na dwóch poziomach - geopolitycznym oraz wewnętrznym, realizowanym na poziomie państw narodowych. Proces ten wpisuje się w kryzys hegemonii zachodniej w globalnym systemie kapitalistycznym oraz strukturalny kryzys gospodarczy kapitalizmu. Islamofobia okazuje się funkcjonalnym narzędziem zarządzania kryzysami. Po pierwsze, stanowi element legitymizacji polityki imperialistycznej, kreując obraz nowego wroga Zachodu. Po drugie, jest narzędziem neoliberalnej polityki „dzielenia i rządzenia” klasami podporządkowanymi w Europie i Ameryce Północnej.
\end{abstract}

Słowa kluczowe: islamofobia, ekonomia polityczna, imperializm, walka klas, rewolucja islamska, Bliski Wschód, neoliberalizm 


\section{Wstęp}

Ksenofobia rozgościła się na dobre na zachodnich salonach, w debacie publicznej, retoryce politycznej i mediach głównego nurtu. Tak naprawdę nigdy ich na nie opuściła. Powojenny konsens antyfaszystowski i efekt dekolonizacji nie wyrugowały całkowicie stereotypów i uprzedzeń wobec mniejszości oraz społeczeństw niezachodnich. Niemniej w ciagu minionego ćwierćwiecza, gdy uprzedzenia te zaczęły się szerzyć pod postacią islamofobii, ich obecność w przestrzeni publicznej stała się bardziej bezwstydna. W odróżnieniu od innych form szowinizmu manifestowanie wrogości wobec muzułmanów na ogół uchodzi bezkarnie. W liberalnych i konserwatywnych mediach głównego nurtu o islamie i jego wyznawcach można mówić językiem, który wywołałby skandal, gdyby został użyty na przykład wobec Afroamerykanów. Stereotypy i fałszywe informacje, nieuprawnione generalizacje i stosowanie odpowiedzialności zbiorowej, uprzedzenia religijne i kulturowe, obelżywe sformułowania i język pogardy, w wielu przypadkach czerpiące garściami wprost z dyskursu antysemickiego $z$ lat trzydziestych minionego stulecia, można znaleźć zarówno w serwisach informacyjnych, jak i w uchodzącej za poważną publicystyce. W największym polskim dzienniku - Gaz̨ecie Wyborczej - drukowano jawnie islamofobiczne teksty Oriany Fallaci, a w roli eksperta od islamu występuje na jej łamach muzułmański arabo- i islamofob Piotr Ibrahim Kalwas (Fallaci 2001; Bobako 2017, 54-74). W serwisach informacyjnych muzułmanów, szczególnie arabskich, przedstawia się zgodnie z najgorszymi wzorcami rasistowskimi - jako odczłowieczony, groźny i dyszący nienawiścią tłum. Ministrowie Jarosław Gowin i Witold Waszczykowski jawnie odwołują się do islamofobicznej retoryki, usprawiedliwiając antyuchodźczą politykę polskiego rządu w mediach i na forum międzynarodowym (Majmurek 2017; Prończuk 2017; Rajkowska 2010a; Rajkowska 2010b ).

Fenomen islamofobii, której doświadczamy dziś w Europie, nie jest fałszywa odpowiedzią na realne zagrożenia stwarzane przez ekspansję dżihadyzmu Organizacji Państwa Islamskiego, al-Kaidy czy Boko Haram. Rzecz jasna rozwija się ona w kontekście sporadycznych zamachów w europejskich miastach, stanowiących odprysk wojen w Syrii, Iraku i Libii, w które zaangażowały się mocarstwa zachodnie. Podobnie jak jej wcześniejsza fala, związana z atakami z 11 września 2001 roku. Nowej islamofobii nie da się jednak zredukować do tego „kontekstu terrorystycznego”. Zaczęła się wiele lat, a nawet dekad przed tymi wydarzeniami. Właściwym kontekstem dla wznoszenia się kolejnych fal islamofobii sa natomiast pogłębiające się problemy ekonomiczne i społeczne, które od lat siedemdziesiątych dwudziestego wieku przyjmuja postać strukturalnego kryzysu kapitalizmu. Wśród wielu jego przejawów najistotniejsze sa: spadek stopy akumulacji, trwały spadek tempa wzrostu gospodarczego, obniżenie rentowności przedsięwzięć gospodarczych z wyjątkiem sektora finansowego oraz kryzys zachodniej dominacji w globalnych stosunkach gospodarczych. Po 
stronie konsekwencji społecznych kryzysu w rozwiniętych krajach kapitalistycznych należy wymienić przede wszystkim rosnące nierówności, bezrobocie, pauperyzację klasy średniej i pracowników, demontaż sektora publicznego i destabilizację stosunków pracy. W planie międzynarodowym obserwujemy erozję ładu opartego na prawie międzynarodowym i stojących na jego straży instytucjach, militaryzacje sprawowania hegemonii oraz wzrost rywalizacji imperialistycznej.

Wrogość do islamu przetacza się przez świat zachodni pod koniec lat siedemdziesiątych, gdy zaostrzający się kryzys toruje drogę neoliberalnej kontrrewolucji, a w Iranie upada reżim proamerykańskiego szacha Rezy Pahlawiego. Koncepcje „zderzenia cywilizacji”, doktryny Likudu i Projektu Nowego Amerykańskiego Stulecia powstają w okresie naznaczonym przez zaciskanie pasa, deregulacje, prywatyzacje, cięcia wydatków publicznych i skutki kolejnych kryzysów: finansowego z roku 1987, azjatyckiego z lat 1997-1998 oraz wywołanego przezeń gigantycznego krachu funduszu inwestycyjnego LTCM. Absolutną wojnę z terroryzmem poprzedza krach na giełdzie nowych technologii NASDAQ i upadek Worldcomu (kolejnego korporacyjnego giganta) w latach 2000-2001. Z kolei grunt pod najnowszą falę islamofobii przygotował największy od 1929 roku kryzys, który zaczął się jako krach finansowy lat 20072009 i pierwsza w historii globalna klęska głodu, a potem przekształcił się w kryzysy długu publicznego oraz nową, ,wielką depresje”, która wciąż na dobre nie została przełamana (Foster i McChesney 2015). Nie jest to zwykła koincydencja czasowa. Gdy kapitalizm wpada wkłopoty, klasy rządzące staraja się bronić swoich przywilejów, zarządzając kryzysem. Konsekwencje takich działań na polu międzynarodowym, społeczno-ekonomicznym i kulturalnym napędzają zapotrzebowanie na kozła ofiarnego i obsadzanego w tej roli „innego”. O ile w czasie wielkiego kryzysu 1929 roku rolę tę narzucono Żydom, to od ponad trzech dekad coraz częściej przypisuje się ją muzułmanom lub muzułmańskim imigrantom.

Rzecz jasna muzułmanie pełnili funkcję wielkiego innego Zachodu właściwie od momentu pojawienia się ich religii i w całym jej historycznym rozwoju. To w odniesieniu do nich w kulturze i polityce europejskiej ujawniły się pierwsze rysy rasistowskie. Od eksterminacji hiszpańskich morysków i marranów w początkach siedemnastego wieku kategoria innego zaczęła nasiąkać treściami specyficznie nowoczesnymi. Przynależność do wspólnoty religijnej, która mogła zostać porzucona pod przymusem lub na drodze dobrowolnej konwersji, ustępowała niezbywalnej tożsamości rasowej. Moryskowie i marranie padli ofiarą masowych prześladowań nie dlatego, że byli - odpowiednio - muzułmanami lub żydami, ale pomimo tego, że nawrócili się na chrześcijaństwo. Chyba po raz pierwszy w historii Zachodu uznano wówczas, że pod fasadą oficjalnego wyznania może tkwić jakaś ukryta tożsamość, której nie da się wymazać - islamska rasa (Wielgosz 2002; Bobako 2017, 138-142). W ciagu kilku minionych dekad, po kompromitacji swojej wersji biologicznej, rasizm ewoluował ku formie kulturowej. Przypisuje ona kategoriom takim jak moralność wspólnotowa, religia czy obyczajowość tę samą 
niezbywalność, która jeszcze siedemdziesiąt lat temu miała rzekomo wynikać z koloru skóry. Ale przejście od rasizmu biologicznego do kulturowego nie jest jedyną z transformacji odróżniających historyczne formy fobii wobec wyznawców islamu od ich dzisiejszych postaci.

Dzisiejsza islamofobia nie jest prostym rozwinięciem dawnej niechęci do muzułmanów. Zarówno w zakresie swej treści, form przejawiania się, spełnianych funkcji politycznych, jak i konsekwencji społecznych stanowi zjawisko nowe, osadzone w ekonomii politycznej, kontekście międzynarodowym i układach sił klasowych charakteryzujących kapitalizm w wersji neoliberalnej, którego ekspansja przypada na czas schyłku dotychczasowego układu hegemonicznego. Geopolityczne i ekonomiczne aspekty współczesnej islamofobii nakładają się na siebie, przeplatają i wzajemnie wzmacniają. Nie sposób ich rozdzielić i nie wolno izolować, ale mimo to warto poddać je analizie, patrząc przez pryzmat każdego z nich z osobna.

\section{Kryzys strukturalny i geopolityka islamofobii}

\section{3 - wojna październikowa, kryzys naftowy, czyli świat arabski na celowniku}

W planie geopolitycznym warunki dla rozwoju dzisiejszej islamofobii zaczynają się kształtować podczas arabsko-izraelskiej wojny październikowej 1973 roku i będącego jej konsekwencja kryzysu naftowego. Trwający od 1968 roku rozwój rewolucji palestyńskiej, która realnie zagroziła proamerykańskim reżimom na Bliskim Wschodzie, widmo klęski Izraela zaledwie 5 lat po jego wielkim triumfie w wojnie sześciodniowej 1967 roku, w której Izrael zaatakował i pokonał swoich najważniejszych arabskich sąsiadów - Egipt, Syrię i Jordanię - oraz solidarna akcja państw OPEC prowadząca do urealnienia cen węglowodorów (czyli ich podwyżki) wstrząsnęły Zachodem (Corm 2003, 172-209; Varoufakis 2015, 116-121). Świat arabski po raz pierwszy tak wyraźnie objawił się tamtejszym strategom jako zagrożenie dla hegemonicznych interesów USA i jego sojuszników w najistotniejszym pod względem strategicznym regionie surowcowym planety.

Wagę wydarzeń politycznych wzmocnił fakt, że nałożyły się one na kryzys gospodarczy postępujący w transatlantyckich ośrodkach kapitalizmu od końcówki lat sześćdziesiątych i zapowiadający zmierzch reżimu akumulacji ukształtowanego po II wojnie światowej, zwanego też ładem z Bretton Woods (Wallerstein 2004, 62-86; Wallerstein 2007, 111-128; Wallerstein 2015). Włączenie się do globalnej rywalizacji Europy i Japonii - dwóch ośrodków kapitalizmu odbudowanych po zniszczeniach wojennych - de facto zakończyło amerykańską hegemonię oraz ograniczyło ekonomiczne korzyści z niej płynące. Najpierw w USA, a potem też w skali globalnej ekspansja kapitału uległa wyhamowaniu. Spadająca stopa akumulacji i ogólne spowolnienie dynamiki gospodarczej sprowokowały próby rozruszania systemu przez jego finansjeryzację i restaurację władzy klasowej (Harvey 2007). Odejście od standardu złota 
i upłynnienie kursu dolara w latach 1972-1973, atak na zdobycze pracownicze skutkujący zablokowaniem wzrostu płac w USA i pojawieniem się bezrobocia strukturalnego w Europie, zwiększenie roli wielkich korporacji w gospodarce oraz odejście od energooszczędnych zbiorowych form konsumpcji na rzecz energochłonnej konsumpcji indywidualnej doprowadziły do wzrostu znaczenia cen ropy naftowej i wyłonienia się standardu ropy jako miernika kondycji gospodarki, a zarazem narzędzia nacisku w stosunkach międzynarodowych (Pobłocki 2017, 160-162; Mitchell 2013; Klare 2006)ํ․

Paradoksalnie przepływ finansów do krajów naftowych po 1973 roku okazał się wsparciem dla polityki neokolonialnej. Po pierwsze dlatego, że petrodolary wzmocniły arabskich konserwatystów i islamistów zwalczających antyimperialistyczną lewicę na Bliskim Wschodzie i w Afryce Północnej. Po drugie, pieniądze zarobione na ropie rządy Półwyspu i Zatoki lokowały w europejskich i amerykańskich bankach, które z kolei oferowały je krajom Trzeciego Świata i Europie Wschodniej w formie kredytów o zmiennym oprocentowaniu. Państwa te potrzebowały środków do finansowania projektów modernizacyjnych i radzenia sobie ze skutkami globalnego spowolnienia gospodarczego. Na początku następnej dekady, gdy Waszyngton zaczął walkę ze wzrostem inflacji, podwyższając oprocentowanie kredytów, kraje rozwijające się wpadły w pętle zadłużenia i znalazły się na łasce i niełasce wierzycieli. Uderzyło to także w świeckie reżimy arabskie związane z trzecioświatowym projektem Bandungu (Amin 2014).

Świat arabski wcześniej też dostarczał przywódcom zachodnim powodów do bólu głowy. Dekolonizacja, klęska mocarstw kolonialnych w wojnie z Egiptem w 1956 roku, rewolucje i ustanowienie nacjonalistyczno-populistycznych reżimów w Iraku, Syrii, Egipcie, Jemenie Południowym, Tunezji i Algierii, a wreszcie silna lewica marksistowska w regionie były problemami dla amerykańskich, brytyjskich czy francuskich wpływów (Corm 2003, 139-169; Alexander 2005; Pappe 2015, 53-61; Halliday 2009, 112-148). Nigdy jednak nie uznawano ich za zagrożenie na własnym terenie. Przejście od „problemów” do „zagrożeń” nastapiło właśnie w okolicach kryzysu naftowego. Wcześniejsze nacjonalizacje, polityki redystrybucyjne i lewicowa retoryka nie wywołały takiego szoku, bo ich skutki nie były odczuwalne bezpośrednio w Londynie, Paryżu czy Nowym Jorku. Teraz tak się stało. Rosnąca rola ropy naftowej przełożyła się na powstanie mglistej wizji „,arabskiego zagrożenia”. Początkowo jeszcze definiowano je w kategoriach politycznych i ideologicznych, usiłując wpisać je w ramy zimnej wojny z Blokiem Wschodnim (co okazało się w dużej mierze nieuzasadnione i tylko pozbawiło działania Zachodu skuteczności). W tych ramach ideologicznych do rangi lokalnego sojusznika w walce z ,arabskim zagrożeniem” awansowały ruchy islamistyczne. Te ruchy

\footnotetext{
${ }^{1}$ Wzrost lub spadek cen ropy jest funkcją popytu, który z kolei wskazuje na wzrost lub stagnację PKB. W 1973 roku kraje arabskie OPEC spróbowały odwrócić tę zależność i pogłębić stagnację, wprowadzając embargo i w rezultacie podnosząc ceny w odwecie za wsparcie Izraela przez kraje zachodnie.
} 
odwołujące się do radykalnej retoryki, a często także do przemocy, zyskały wsparcie ze strony konserwatywnych reżimów Półwyspu Arabskiego i Zatoki, wzbogaconych nagle dzięki naftowemu boomowi.

Powstało wtedy coś w rodzaju trójkąta bliskowschodniego. W jego skład weszły Stany Zjednoczone, państwa Półwyspu Arabskiego oraz prawicowe ruchy islamistyczne. W ramach trójkąta Stany Zjednoczone wspierają i zbroją Arabię Saudyjską oraz emiraty (i w ten sposób odzyskują część pieniędzy płaconych za drożejącą ropę). W zamian Waszyngton korzysta na wsparciu tych reżimów dla ruchów islamistycznych walczących z arabską lewica (także i to wsparcie finansowano za petrodolary). Arabskie monarchie cieszą się protektoratem Waszyngtonu. Z kolei radykałowie korzystaja z hojnego wsparcia finansowego i technicznego, w zamian za które nie atakuja skorumpowanych reżimów. Uzależnienie USA od sojuszu z Saudami i władcami Zatoki, którzy z kolei płacą haracz islamistom i dżihadystom (dzięki temu eksportując radykalizm islamski i kupując spokój u siebie), trwa do dziś i wpływa na obecną sytuację międzynarodową oraz skuteczność działań USA w regionie.

W latach siedemdziesiątych i osiemdziesiątych trójkąt ten przynosił Waszyngtonowi wymierne sukcesy w postaci zwasalizowania Egiptu (będącego wcześniej biegunem arabskiej rewolucji), podkopania pozycji Algierii, wzmocnienia Izraela i nieudanej rewolucji - oraz udanej kontrrewolucji - w Jordanii (Czarny Wrzesień 1970 roku). Na Półwyspie Arabskim, pod ochroną Waszyngtonu i za pieniądze z naftowego boomu, uformował się regionalny ośrodek władzy finansowej i ideologicznej - w postaci wahhabizmu - wywierający coraz większy wpływ na okoliczne społeczeństwa i rządy. Jego rolę początkowo ograniczała potęga Iranu, który od czasu sponsorowanego przez CIA i wywiad brytyjski zamachu stanu w 1953 roku stanowił oparcie dla interesów amerykańskich.

\section{Szok rewolucji w Iranie 1978-1979 i początek islamizacji Arabów}

Wydarzeniem, które zmieniło wszystko, była rewolucja w Iranie. Wskutek obalenia proamerykańskiego szacha i szybkiej reorientacji Iranu w stronę Republiki Islamskiej w przestrzeni Bliskiego Wschodu wyłonił się trzeci biegun, niezależny zarówno od Zachodu, jak i od Bloku Wschodniego (Keddie 2007; Halliday 2002, 48-80). Teheran pod względem strategicznym znalazł się zatem w podwójnym oblężeniu. Zachód atakował Iran bezpośrednio w czasie tzw. kryzysu zakładników w 1980 roku i pośrednio, gdy wspierał (na spółkę z Blokiem Wschodnim) Irak - agresora w wojnie iracko-irańskiej 1980-1988. Republika Islamska odpowiadała na to polityką typową dla reżimów rewolucyjnych otoczonych przez wrogów, którzy dążą do ich zduszenia - wspierała ruchy rewolucyjne szukające inspiracji w Iranie. Strategia ta do dziś odznacza się ponadwyznaniowym internacjonalizmem zupełnie obcym wahhabickim fundamentalistom z Rijadu. Republika z większością szyicką nie wahała się 
pomagać sunnickim ruchom w rodzaju Braci Muzułmanów, a później np. palestyńskiego Hamasu. Siła tej rewolucyjnej strategii dała o sobie znać w czasie zakończonej porażka interwencji USA, Włoch i Francji w Libanie w latach 1982-1983. Wspierany przez Iran ruch oporu zmusił do odwrotu siły mocarstw i zaczął spędzać sen z powiek ich ekspertom w dziedzinie strategii. W nowej sytuacji islam polityczny, wcześniej wspierany przez Zachód jako alternatywa dla arabskiej lewicy, stawał się coraz większym problemem.

Coraz częściej problemy, jakie napotykała zachodnia kontrola nad regionem, zaczęto wiązać z islamem i rzekomą specyfiką społeczeństw, w których jego wyznawcy stanowią większość. Temu sposobowi myślenia sprzyjał kryzys Trzeciego Świata i projektu Bandungu rozpadającego się pod wpływem zadłużenia oraz prawicowych zamachów stanu. Tracił on znaczenie jako realna alternatywa dla bipolarnego podziału Wschód-Zachód. W tej roli amerykańscy stratedzy i publicyści coraz chętniej obsadzali świat islamski, początkowo dość paradoksalnie utożsamiany z mniejszościowym irańskim szyizmem rewolucyjnym. Tak czy inaczej właśnie wtedy zaczął się proces ureligijnienia Arabów i Irańczyków. O ile do niedawna aspiracje i dążenia społeczeństw Bliskiego Wschodu i Afryki Północnej opisywano w kategoriach politycznych, ekonomicznych i narodowych, to w latach osiemdziesiątych pojawiły się pierwsze tendencje do interpretowania ich jako konsekwencji dominującej religii muzułmańskiej na tych terenach i jej wpływu na wyobraźnię polityczna, prawo oraz naturę więzi społecznych. Co ciekawe, nie przeszkadzało to Waszyngtonowi w podjęciu decyzji o użyciu dżihadystów przeciw swojemu najważniejszemu ówczesnemu konkurentowi geopolitycznemu, czyli ZSRR. W czasie radzieckiej interwencji w Afganistanie (1979-1988) przeciwko siłom radzieckim walczyło kilkadziesiąt tysięcy islamistycznych ochotników z amerykańską bronią i know-how oraz saudyjskimi pieniędzmi. Klęska Moskwy znacznie wzmocniła ruchy dżihadystowskie, pozwalając im po raz pierwszy myśleć o zrzuceniu jarzma w postaci amerykańskiego protektora.

Ostatnie wyspy arabskiej lewicowości znikają na początku lat dziewięćdziesiątych wraz z obaleniem Ludowo-Demokratycznej Republiki Jemenu przez wojska konserwatywnego Jemenu Północnego, wspieranego przez Zachód. Dzięki antymarksistowskiej ofensywie Waszyngtonu i jego sojuszników na początku ostatniej dekady dwudziestego wieku problem arabskiego antyimperializmu i związanego z nim ,arabskiego zagrożenia” znika. Poza paroma wyjątkami świat arabski zostaje podporządkowany imperialnej eksploatacji i kontroli. Różnorodne, często biegunowo odmienne ruchy islamskie, które przyczyniły się walnie do tego stanu rzeczy, są silniejsze niż dziesięć lat wcześniej, ale wciąż pozostają w mniejszości. Od izolowanego Iranu, przez demokratyczne lub autorytarne nurty islamu politycznego, aż po salaficki dżihadyzm powoli wchodzą one w rolę tych, którzy mówia głosem uciskanych. Ich realną bazą wciąż sa jednak nie tyle szerokie masy społeczeństw arabskich, co raczej rzekoma 
siła przypisywana im w Waszyngtonie czy Londynie oraz pieniądze Rijadu (z wyjątkiem ruchów szyickich takich jak libański Hezbollah).

\section{Upadek Bloku Wschodniego i szukanie nowego wroga}

Kiedy w latach 1989-1990 rozsypywał się Blok Wschodni, amerykański kompleks militarnoprzemysłowy, obejmujący 30\% gospodarki, stanął w obliczu widma upadku. W tej sytuacji poszukiwanie nowego wroga okazało się kwestią przetrwania amerykańskiego supermocarstwa (Amin 2004, 95-108). O kierunku tych poszukiwań zdecydowały dwie okoliczności. Pierwsza to ograniczenia neoliberalnego reżimu akumulacji kapitału, ujawniające się pod postacią coraz częstszych i coraz głębszych krachów finansowych (1987, 1997-1998, 2000-2001, 2007-2008), a także osłabienia sektora produkcyjnego i przejścia USA od pozycji największego eksportera do pozycji głównego importera kapitału (Varoufakis 2015, 131-134). Słabnąca potęga gospodarcza i wzrost roli finansjery, pasożytującej na wartości wyprodukowanej we wcześniejszych okresach i w innych sektorach, skłoniły amerykańskie elity do częstszego sięgania po przemoc zbrojną i zarządzanie nastrojami społecznymi przy pomocy strachu przed „innym”. Ujmując to nieco inaczej, ekonomia polityczna militaryzacji stosunków międzynarodowych w latach dziewięćdziesiątych polegała na tym, że zarządzanie gospodarką odczuwająca strukturalne konsekwencje trwałego osłabienia dynamiki PKB skoncentrowane było na zapewnianiu rentowności kapitału nie za pośrednictwem innowacji i wytwarzania wartości, ale poprzez przesuwanie jej między sektorami - z sektora produkcyjnego, usług publicznych i systemu zabezpieczeń socjalnych do sektora finansowego - oraz w formie renty imperialnej, między centrum a peryferiami globalnej gospodarki - z globalnego Południa na Północ za pośrednictwem zadłużenia, globalnego arbitrażu pracy, narzucania niesymetrycznej liberalizacji i nierównomiernej wymiany, dostosowań strukturalnych, a wreszcie zbrojnej kontroli nad regionami strategicznymi i surowcowymi (Amin 2005; Ramonet 2006; Golub 2007; Gresh 2008).

Druga okoliczność to kryzys lewicy i powszechny odwrót od marksizmu. Intelektualny regres w środowiskach postępowych, ich ucieczka od polityki i ekonomii wyrażająca się rozkwitem różnych nurtów postmodernizmu, otworzył pole dla ukonstytuowania się konserwatywnej hegemonii kulturalnej podważającej materialistyczne i krytyczne ujęcia stosunków międzynarodowych. Pod hasłem głoszącym, że „kultura ma znaczenie” (Huntington i Harrison 2003), perspektywa konfliktów interesów ukształtowanych historycznie zaczęła ustępować mglistym wizjom ahistorycznych różnic tożsamościowych (Michaels 2007). Na takim właśnie podłożu rozwijały się koncepcje usiłujące zanegować kulturowy i religijny związek islamu z Zachodem. Karierę zrobiło zwłaszcza pojęcie judeochrześcijaństwa, którego początki sięgają kilku dekad wstecz. Z jednej strony miało ono 
pomóc przezwyciężyć tradycyjny antysemityzm Kościoła katolickiego, ale jednocześnie stało się pseudouczoną formą zanegowania teologicznego związku islamu z judaizmem oraz chrześcijaństwem, sugerująca jego radykalną obcość w Europie (Corm 2007, 114-115).

Obok wykluczającej dla islamu koncepcji judeochrześcijaństwa w pejzażu ideologicznym lat dziewięćdziesiątych pojawiły się dwie fundamentalne konstrukcje, na których zbudowana została islamofobia, jaką dziś znamy. Pierwsza ma charakter teoretyczny, druga politycznowojskowy. Koncepcja zderzenia cywilizacji sformułowana przez Samuela Huntingtona przepisuje na nowo mapę konfliktów rozgrywających się na świecie, nie rysując linii frontów wzdłuż interesów narodowych, ekonomicznych czy politycznych, ale podporządkowując je wszystkie nadrzędnej instancji cywilizacji (Huntington 1997). Zamiast na bloki ideologiczne i klasowe Huntington dzieli świat na cywilizacje, przy czym sercem tego pojęcia czyni religie i ich rzekomo wszechogarniający wpływ. W tej ahistorycznej i anachronicznej koncepcji przed umocowanymi w tradycji religijnej tożsamościami nie da się uciec. W przekonaniu o niezbywalnym charakterze tożsamości dochodzi do głosu ahistoryczny i rasistowski rdzeń koncepcji Huntingtona. Wzmacnia go przeświadczenie, że cywilizacje oparte na nieprzekładalnych wzajemnie kodach kulturowych i moralnych skazane sa na nieustanny konflikt. Ta abstrakcyjna matryca ideologiczna zainspirowała amerykańskich neokonserwatystów i ich europejskich odpowiedników. Z otwartymi ramionami powitali ją też oficjalni orientaliści Białego Domu w rodzaju Fouada Ajamiego i Bernarda Lewisa, rozwijający podobne idee już wcześniej. Po raz pierwszy jednak została ona zastosowana i wypełniona treścia polityczna przez izraelską partię Likud, która w latach dziewięćdziesiątych skutecznie przepisała okupację Palestyny i palestyński opór na kategorie huntingtonowskie.

Korzystając z dobrej koniunktury ideologicznej wywołanej ekspansja neoliberalizmu i zapaścią intelektualną lewicy, doktryna Likudu sprzedała światu odpolitycznioną i odhistorycznioną wizję konfliktu z Palestyńczykami. Osadzoną w kontekście historycznym, antykolonialna walkę o prawo do ziemi i demokratycznego samostanowienia przedstawiono w owej wizji jako terrorystyczną agresję stanowiącą wyraz irracjonalnej antysemickiej nienawiści zakorzenionej w islamie (Klein 2005). Zarówno dyskurs Huntingtona, jak i izraelskiego Likudu sugerowały zatem, że źródłem konfliktów i oporu przeciwko obecności USA i polityce izraelskiej na Bliskim Wschodzie jest natura islamu jako cywilizacji. Miałaby ona być wroga nowoczesności, niezdolna do modernizacji, obca sekularyzmowi, niedająca się pogodzić z demokracją i prawami człowieka. Ujęcie, w ramach którego przypisywano społeczeństwom arabsko-muzułmańskim esencjalną irracjonalność (charakteryzować miała ona przede wszystkim słynną, ,arabską ulicę”) utorowało drogę do ich depolityzacji, czyli odmowy uznania ich za równoprawnego partnera politycznej negocjacji. Z jednej strony dostarczyło to ideologicznego usprawiedliwienia dla wsparcia arabskich dyktatur, a z drugiej argumentów za kryminalizacją oddolnych ruchów dążących do demokratyzacji i samostanowienia. Rzecz jasna 
stosowanie przemocy wobec tak określonego przeciwnika można przedstawiać jako całkowicie uprawnione. Odmawiając uznania politycznej podmiotowości arabskich klas ludowych, amerykańscy i izraelscy neokonserwatyści przygotowali ideologiczny grunt pod napiętnowanie każdego jej przejawu mianem terroryzmu. Izraelskie władze stosują tę strategię w przypadku każdej formy antykolonialnego oporu Palestyńczyków - od zbrojnej walki oblężonej Strefy Gazy, przez pokojowe protesty przeciw murowi separacyjnemu i nielegalnym osiedlom na Zachodnim Brzegu, aż po wezwania do międzynarodowego bojkotu okupanta (Gresh 2015).

W latach dziewięćdziesiątych ideologiczna opowieść o abstrakcyjnym islamie jako źródle irracjonalnej wrogości do Zachodu stanowiła tło I Wojny w Zatoce, powietrznej okupacji Iraku, zaostrzającej się okupacji i kolonizacji Palestyny, interwencji w Somalii, konfliktów w Sudanie i Afganistanie. Zainfekowała język mediów i dyskurs polityczny, stając się centralnym elementem neokonserwatywnej wizji międzynarodowej polityki i polityki bezpieczeństwa. Znalazła poczesne miejsce zarówno w Projekcie Nowego Amerykańskiego Stulecia, think tanku założonym w 1997 roku przez ludzi, którzy później weszli do Białego Domu wraz z George'em W. Bushem (Paul Wolfowitz, Richard Perle, Lewis Libby), jak i w nowej strategii energetycznej USA z 2001 roku, przygotowanej przez sekretarza obrony Busha, Donalda Rumsfelda i wiceprezydenta Dicka Cheneya. Zarówno dokument Rebuilding America's Defenses (2000) Projektu Nowego Amerykańskiego Stulecia, jak i strategia energetyczna zgrabnie łączyły dążenie do militarnej kontroli nad bliskowschodnimi zasobami ropy naftowej z ideologicznym kamuflażem sugerującym, że nowy interwencjonizm jest konieczny dla powstrzymania rzekomej ekspansji islamu, która zagraża demokracji i amerykańskiemu stylowi życia. Dokumenty te i ich założenia ideologiczne dostarczyły uzasadnienia dla inwazji na Afganistan i Irak na długo przed zamachami z 11 września.

W ciagu ostatnich dwudziestu pięciu lat „zagrożenie islamskie” zastąpiło na scenie międzynarodowej arabski antyimperializm. Na poziomie społecznym procesowi temu odpowiadało zastapienie pojęcia walki klas przez narrację o mniejszościach i nieudanej integracji.

\section{Kryzys strukturalny i ekonomia polityczna islamofobii}

Jeszcze w połowie lat dziewięćdziesiątych zamieszki ogarniające przedmieścia Paryża prezentowano jako wybuch wściekłości coraz bardziej marginalizowanej i biedniejącej młodzieży z klas pracujących. Widać to doskonale w Nienawiści Mathieu Kassovitza, historii o trójce mieszkańców robotniczej dzielnicy, których kondycja klasowa ubarwiona jest wprawdzie rysem tożsamościowym - jeden jest żydem, drugi muzułmaninem, trzeci katolikiem afrykańskiego pochodzenia - ale nie ma to większego znaczenia. Tożsamość niczego tu nie wyjaśnia, na nic, ani za nic nie odpowiada, nie ma żadnego głębszego sensu - zostaje 
zredukowana do kontekstu życia rodzinnego bohaterów. Zaledwie dziesięć lat później, w połowie pierwszej dekady dwudziestego pierwszego wieku nastrój zmienił się radykalnie. Rozruchy, które ogarnęły kilkadziesiąt francuskich miast, rozlewając się na pograniczne obszary Belgii i Niemiec w roku 2005, w relacjach mediów i retoryce polityków całkowicie straciły swoje podłoże klasowe. Ich źródeł nie szukano w postępującej pauperyzacji i neoliberalnej polityce zaciskania pasa biednym, ale w religijnej i kulturowej tożsamości protestujących. Nawiązując do znanego hasła Braci Muzułmanów (,islam jest rozwiązaniem!’), powiedzieć można, że dla zawiadujących francuską opinią publiczną islam stał się uniwersalną odpowiedzią na pytanie o przyczyny protestów i problemów społecznych. Ta zmiana optyki dobrze obrazuje transformację, jakiej uległa debata w całej Europie, wskazując także na ekonomię polityczną tej przemiany. Rzecz jasna obydwa procesy zaczęły się na długo przed rokiem 1995 i nie zakończyły się w roku 2005.

\section{Dziel i rządź, albo tradycja urasowienia i współczesność segmentacji}

Jednym z zasadniczych źródeł nowoczesnego rasizmu jest dążenie kapitału do podporządkowania sobie siły roboczej. W długiej historii formowania się stosunków kapitalistycznych urasowienie klas podporządkowanych i ich segmentacja zgodnie z liniami rasowymi i tożsamościowymi stanowiły sposób rozbrajania ich oporu (Bobako 2011; Silver 2009; Urbański 2014).

Obydwie te strategie narzucania, a zarazem legitymizowania reżimu eksploatacji pojawily się już u progu nowoczesności. W siedemnastym wieku język i ideologia hierarchii rasowej wspierały system poddaństwa chłopów w Rzeczpospolitej szlacheckiej. Pańszczyźnianą siłę roboczą nazywano tu „czernią”, a jej niewolny status uzasadniała ideologia sarmatyzmu, uznająca supremacje szlachty jako rodzaj panowania kolonialnego nad istotami niższymi rasowo. Urasowienie klas i grup podporządkowanych naznaczyło dyskurs i praktykę republikanizmu przełomu osiemnastego i dziewiętnastego wieku. Patetyczny uniwersalizm rewolucji francuskiej opierał się na wykluczeniu z ciała suwerennego narodu robotników, biedoty, migrantów i kobiet. Na poziomie dyskursywnym wspólnym mianownikiem części tych grup była także różnica rasowa. Przez długie dekady uzasadniała ona odmowę przyznania im praw politycznych i obywatelskich. W tym samym czasie ludy skolonizowane znalazły się w ogóle poza granicami uniwersum praw człowieka. Obydwie te matryce wykluczenia w wielu miejscach nakładały się na siebie. Proletariat metropolii w oczach klas rządzących zyskiwał rysy niższych rasowo społeczeństw niezachodnich. Także praktyki ujarzmiania go opierały się na wzorcach wypracowanych w koloniach. Dla generałów tłumiących robotnicze powstanie w Paryżu w czerwcu 1848 roku buntownicy byli „,arabusami”, nieróżniącymi się specjalnie od podbitych właśnie po ludobójczej kampanii Algierczyków (Grandmaison 2005a; Grandmaison 
2005b). I, rzecz jasna, można ich było bezkarnie rozstrzeliwać. Z kolei migranci z południa Włoch, tworzący siłę roboczą w Turynie czy Mediolanie w pierwszej połowie dwudziestego wieku, określani byli noszącym znamiona rasowego piętna mianem terroni (,ziemiole”). W latach dziewięćdziesiątych dwudziestego wieku w Polsce tendencja urasawiania wróciła w postaci dyskursu o homo sovieticus, pracownikach ukształtowanych przez komunizm, a zatem niedorosłych do demokracji, niezdolnych do odnalezienia się w rzeczywistości rynkowej i decydowania o sobie, irracjonalnych, naiwnych, agresywnych i w ostateczności odmawiających integracji z kapitalistyczną, „normalnością” (Dunn 2008; Bobako 2011).

Druga strategia utrwalania mechanizmów panowania i eksploatacji klasowej jest segmentacja siły roboczej, która często wprowadza różnice rasową między podporządkowanych. W toku swej ekspansji kapitalizm zawsze tworzył podziały w obrębie siły roboczej. Robotnicy, którzy wywalczyli sobie lepsze warunki zatrudnienia, funkcjonowali w otoczeniu mas pracowników nieustabilizowanych (wykluczonych z owoców rozwoju i zdobyczy socjalnych ruchu robotniczego), których Marks nazwał rezerwową armia pracy. Dziś nosi ona miano prekariatu, ale strukturalnie niewiele różni się od swej dziewiętnastowiecznej poprzedniczki. Podobnie jak ona wówczas, ta współczesna jej forma jest wykorzystywana przez kapitał do wywierania presji na płace i zdobycze pracownicze w formie dumpingu socjalnego. W Europie Zachodniej podział na pracowników ustabilizowanych i prekariat pokrywa się w dużej mierze $\mathrm{z}$ podziałami etnokulturowymi i płciowymi. Szeregi prekariatu tworza w dużej mierze kobiety, imigranci, reprezentanci mniejszości etnicznych i religijnych. Kreowanie i podtrzymywanie rzekomej sprzeczności interesów między stabilną i nieustabilizowaną częścią siły roboczej pozwala kapitałowi wywierać skuteczną presję na wszystkich. Może ona być silniejsza o tyle, o ile uda się tę sprzeczność wyrazić w kategoriach tożsamościowych. Także i to zjawisko pojawia się po raz pierwszy w okresie formowania się kapitalizmu w jego euroamerykańskich ośrodkach.

Pierwszym znanym przypadkiem zastosowania podziału rasowego przez klasy rządzące są wydarzenia towarzyszące robotniczo-niewolniczej rebelii w amerykańskich koloniach Wielkiej Brytanii w latach siedemdziesiątych siedemnastego wieku, gdy przestraszeni właściciele środków produkcji wykreowali antagonizm między niewolnikami z Afryki a resztą siły roboczej (Kowalewski 1999). Dziś widzimy, jak segmentacja działa, przeciwstawiając sobie migrantów różnych narodowości. Mniej więcej od lat sześćdziesiątych migrancka, sprekaryzowana siła robocza znajdowała zatrudnienie na najgorzej opłacanych stanowiskach pracy w dynamicznie rozwijającym się przemyśle Wielkiej Brytanii, Francji, Niemiec czy krajów Beneluksu. W znacznej części pochodziła ona z postkolonialnych krajów muzułmańskich (Maghrebu, Bliskiego i Środkowego Wschodu oraz Azji Południowo-Wschodniej). Od momentu rozszerzenia Unii Europejskiej w 2004 roku zasiliła ja kilkumilionowa rzesza migrantów z Europy Wschodniej (Polski, Bułgarii, Rumunii, Węgier, krajów bałtyckich, a od 
niedawna także Ukrainy). Początkowo konkurencja między tymi grupami pracowników nowych imigrantów i potomków imigrantów - nie miała dużego znaczenia politycznego. Sytuacja zmieniła się po krachu finansowym lat 2007-2008 i gwałtownym wzroście bezrobocia. Hasła o zagrożeniu płynącym ze strony muzułmańskich prekariuszy, rzekomo zabierających miejsca pracy migrantom z Polski, padły na podatny grunt. Rywalizacja o niskopłatne stanowiska zaczęła przybierać postać wrogości na tle etnokulturowym, a nałożyła się na nią ksenofobiczna reakcja ze strony części Brytyjczyków, która dotknęła zarówno Polaków, jak i muzułmanów. W dyskusjach o wzroście nastrojów szowinistycznych w społeczeństwach Europy Wschodniej zwykle przecenia się znaczenie nieprzezwyciężonego historycznego antysemityzmu, a zarazem nie docenia się roli strukturalnych uwarunkowań związanych z peryferyjnym statusem i imigranckim charakterem społeczeństw takich jak polskie czy węgierskie. Tak czy inaczej, antyislamskie uprzedzenia przesyłane do kraju wraz z zarabianymi w Wielkiej Brytanii pieniędzmi stały się jedną z sił napędowych nastrojów islamofobicznych w Polsce (Tamás 2016).

\section{Etapy przepisywania konfliktu klasowego na kategorie kulturowo-tożsamościowe}

Usytuowana na takim tle historycznym i strukturalnym obecna islamofobia okazuje się ideologicznym narzędziem klasowego panowania, wykorzystanym w okresie gospodarczej niestabilności. Kluczem do zrozumienia genezy i natury islamofobii szerzącej się w społeczeństwach europejskich nie jest zatem analiza stosunków międzykulturowych czy międzyreligijnych, ale ekonomia polityczna.

Warto w tym miejscu przypomnieć, że pierwsze tendencje islamofobiczne pojawiły się w konserwatywnym dyskursie medialnym wraz z ujawnieniem się konsekwencji społecznych neoliberalnego zarządzania kryzysem strukturalnym kapitalizmu na przełomie lat siedemdziesiątych i osiemdziesiątych. Początek lat osiemdziesiątych to okres brutalnego ataku polityki neoliberalnej na dobrze uzwiązkowione grupy pracowników przemysłowych, nie tylko w USA i w Wielkiej Brytanii, ale także we Francji. I to właśnie we Francji po neoliberalnym zwrocie prezydenta Mitteranda w 1983 roku doszło do serii strajków w przemyśle samochodowym (1983-1984). Duża część zatrudnionej w nim, bardzo bojowej siły roboczej wywodziła się z migracji z Afryki i Maghrebu. O ile jednak jeszcze kilka lat wcześniej walki pracownicze w tym sektorze nawet w prasie konserwatywnej opisywane były w kategoriach klasowych, to wówczas pojawiły się oskarżenia o inspirację irańską (Breville 2015). Symptomatyczna jest również ewolucja wrogiego strajkującym górnikom języka prasy brukowej w Wielkiej Brytanii. W czasie wielkiego strajku w roku 1984 prasa przeszła od oskarżeń o inspiracje z ambasady ZSRR do sugerowania relacji działaczy górniczych z Libią (Breville 2015). 
Mniej więcej dekadę później tradycyjnie antyarabskie i proizraelskie pismo amerykańskich neokonserwatystów Commentary wykonało znamienny krok, przechodząc od oskarżeń Arabów o agenturalność wobec ZSRR do oskarżeń lewicy zachodniej o agenturalność wobec islamu politycznego ${ }^{2}$.

To, co jeszcze w latach osiemdziesiątych mogło się wydawać absurdalnym wymysłem pseudodziennikarzy Ruperta Murdocha, zaledwie dekadę później znalazło swoje miejsce w tzw. poważnej prasie. W latach dziewięćdziesiątych i w pierwszej dekadzie dwudziestego pierwszego wieku rozruchy na przedmieściach robotniczych straciły posmak klasowego buntu, a ich interpretacje zmonopolizowały dyskursy o niebezpiecznych dzielnicach, kwestii nieudanej integracji migrantów, radykalizacji w meczetach. Klasowa nierówność i ubóstwo zostały w tych dyskursach wyprowadzone z różnicy etnokulturowej, a często po prostu ureligijnione. Symptomatyczna była tu ewolucja analiz z zakresu kwestii miejskiej. Dzielnice, które jeszcze do niedawna opisywano jako robotnicze, nagle zaczęto nazywać gettami migranckimi, choć migrantów było tam znacznie mniej niż dwie dekady wcześniej (Y1lmaz 2016).

\section{Samospełniająca się przepowiednia neoliberalizmu. Ideologia i praktyka}

Margaret Thatcher powiedziała, że nie ma społeczeństwa, są tylko jednostki i ich rodziny, a polityki neoliberalne robia, co mogą, aby w praktyce stworzyć sytuację potwierdzająca te słowa. Neoliberalne zarządzanie kryzysem kapitalizmu oferuje zatem rodzaj samospełniającej się przepowiedni.

W obliczu nieskuteczności prób rozruszania gospodarki, która na początku lat siedemdziesiatych popadła w stagnację, neoliberalny reżim akumulacji stawia sobie mniej ambitne cele - próbuje ratować zyski kapitału. Czyni to kosztem zaspokajania potrzeb społecznych, a warunkiem powodzenia i głównym skutkiem polityk neoliberalnych jest restauracja władzy klasowej. Opisywane już wyżej przesunięcie bogactwa z sektora publicznego, ubezpieczeń społecznych i płac roboczych na rynki finansowe zakładało zerwanie tzw. kompromisów społecznych i złamanie oporu klas podporządkowanych. Odwrócenie redystrybucji i prywatyzacja dóbr wspólnych byłyby niemożliwe bez osłabienia związków zawodowych, obalenia elementów demokracji przemysłowej, skutecznej destabilizacji stosunków pracy i rozerwania sieci solidarności pracowniczej. Warunkiem powodzenia tej strategii było od początku wsparcie ze strony aparatu państwowego i ekspansja jego resortów siłowych, które wbrew antyetatystycznej retoryce neoliberalizmu od kilku dekad stają się coraz silniejsze. Deregulacji kodeksów pracy od lat osiemdziesiatych towarzyszy zaostrzanie kodeksów karnych. Państwo wycofuje się zatem ze swej roli socjalnej, odmawiając zapewniania

2 W Commentary publikowała cała neokonserwatywno-islamofobiczna śmietanka, m.in. Joshua Muravchik, Daniel Pipes, Richard Perle, Irving Kristol, Bernard Lewis i inni. 
spójności społecznej, a przy tym rozwija policyjną kontrolę nad pracownikami, biedotą i migrantami.

Równie istotną rolę w łamaniu oporu pracowników i demontażu państwa dobrobytu odegrała hegemonia kulturowa pozwalająca narzucić ofiarom neoliberalizmu skrojone przezeń okulary ideologiczne. Pomógł w tym ideologiczny kryzys na lewicy. Osłabiona i dobita przez upadek Bloku Wschodniego rozpoczęła ona odwrót od analizy społecznej dokonywanej w kategoriach klasowych i uwzględniającej rolę aparatów państwa. Odbywał się on pod pretekstem wylasowanego przez postmodernistów wyzwolenia od „totalizującego wpływu metanarracji”, a w praktyce pozwolił prawicy zagospodarować opuszczone pole konfliktów społecznych i zastąpić walkę klas jej ulubionymi wojnami kulturowymi.

Neoliberalizm w teorii, a jeszcze bardziej w praktyce, odpolitycznia nierówności i ekonomię. Decyzje dotyczące gospodarki przekazuje w ręce gremiów i instytucji wolnych od kontroli demokratycznej (taka jest faktyczna treść społeczna tzw. niezależności banków centralnych czy rola EBC w strefie euro). Zamiast polityki ekonomicznej na scenę wkracza eksperckie zarządzanie i automatyzm (jak np. w przypadku działania Europejskiego Funduszu Stabilizacyjnego czy procedury nadmiernego deficytu). W miejscu odpolitycznionej ekonomii prawica neoliberalna upolitycznia różnice kulturowe. Oznacza to, że zmianie ulega tu sama treść polityczności. Przestaje być ona kategorią opisującą konflikty interesów ekonomicznych, procesy upodmiotowienia, społecznej zmiany, emancypacji i solidarności, a nabiera konserwatywnych rysów praktyki podporządkowania jednostek wspólnocie pochodzenia i suwerennego wytyczania granic owej wspólnoty poprzez wykluczanie innych.

Wizja społeczeństwa propagowana przez konserwatywnych neoliberałów zakłada, że potrzeba uspołecznienia nie realizuje się przez demokrację na podstawie pozycji klasowej, ale przez rynek na podstawie tożsamości. Odrzuca ona analizę konfliktów społecznych w kategoriach klasowych, przepisując antagonizmy właściwe społeczeństwom kapitalistycznym na kategorie tożsamościowe. Te ostatnie może definiować płeć, pochodzenie etniczne, orientacja seksualna, a także wyznawana religia. Ostatnio tak właśnie dzieje się $z$ islamem.

To przeorientowanie perspektywy analitycznej pełni doniosłą funkcję praktyczną w zarządzaniu frustracjami wywołanymi przez kryzys ekonomiczny. Szukając odpowiedzialnych za bezrobocie, pauperyzację oraz niestabilność klas podporządkowanych, a przede wszystkim narastające poczucie zagrożenia wśród przedstawicieli klas średnich, ideologia neoliberalna odwraca uwagę od strukturalnych problemów kapitalizmu. Usuwa z pola widzenia systemowe i historyczne przesłanki rozsadzających go sprzeczności. W to miejsce wprowadza kwestię tożsamości klas ludowych, fetyszyzując ich wyznaczniki etniczne, rasowe, religijne, seksualne. W zaproponowanej przez nią optyce problemem nie jest kapitalizm, ale niezdolność do elastycznego dostosowywania się, brak innowacyjności i mobilności, które 
charakteryzuja jego ofiary. Zamiast deficytu równości ekonomicznej wprowadza wizję deficytu integracji. Dochodzi do odwrócenia kwestii odpowiedzialności. O ile bowiem równości i sprawiedliwości żąda się od państwa i kapitału, to integracji wymaga się od wyzyskiwanych. Neoliberalny kapitalizm zostaje tu oczyszczony z wszelkich podejrzeń. Znika zatem polityczny wymiar antagonizmów, a kwestia demokracji ustępuje miejsca zarządzaniu społecznymi konsekwencjami kryzysu. W takiej optyce biedni stają się coraz biedniejsi, bo w bogaceniu się przeszkadza im kulturowy balast wyniesiony ze wspólnot pochodzenia. Okazuje się, że główną przyczyną pogłębiających się nierówności nie jest rosnący wyzysk i abdykacja państwa na polu społecznym, ale imigranckie pochodzenie biedniejących robotników. To ono, choć przez ponad dwa pokolenia pozostawało nieistotne, ujawnia się jako podstawowa kategoria analityczna rzekomo pozwalająca uchwycić ich kondycję materialną i źródła problemów. Zastosowanie takiego klucza daje możliwość zasadniczej redefinicji rozumienia klas podporządkowanych i otwiera droge do ich wtórnego urasowienia, które dziś, z oczywistych powodów, dokonuje się w kulturalistycznym sosie.

W konsekwencji dochodzi do zasadniczej zmiany perspektywy w opisie konfliktów społecznych. Zmieniają się ich uczestnicy, transformacji ulegaja pola walk i ich stawki. Zamiast obrazu wielorasowego i wieloetnicznego proletariatu walczącego o równość i redystrybucję narracja neoliberalna kreuje wizję mniejszości (w tym przypadku imigrantów) domagających się uznania ich statusu religijno-kulturowego. Przestrzenią sporu przestaja być miejsca pracy i panujące w nich stosunki produkcji, a staja się nią wspólnoty i miejsca zamieszkania. O ile te pierwsze, choć zawsze osadzone są w konkretnym zakładzie, mają wymiar ogólnospołeczny, to te drugie cechuje tendencja do wiązania się z określonym terytorium i ekskluzywną grupa. Stawką walki nie są już uniwersalne prawa, rozstrzygnięcia reformujące proces wytwarzania społecznego bogactwa i polityczna kontrola jego redystrybucji. Są nią natomiast ekskluzywne przywileje etnokulturowe zlokalizowane poza sfera produkcji i polityki demokratycznej. Także rozstrzygnięcia walk tracą wymiar ogólny. Walkę z nierównością zastępuje walka z dyskryminacja, solidarność klasowa znika na rzecz lojalności wspólnotowej, uniwersalna emancypacja oddaje pole partykularnemu interesowi grupy.

Jak widzimy, neoliberalna polityka wciela w życie rzeczywistą neoliberalną wizję społeczeństwa. Prywatyzacje, deregulacje, cięcia i zaciskanie pasa popychają najsłabsze sektory klas pracowniczych w stronę tożsamości. Niszcząc organizacyjne i instytucjonalne zaplecze świadomości klasowej podporządkowanych (związki zawodowe, usługi publiczne, sfera prawa społecznego, stowarzyszenia, organizacje polityczne i kultura robotnicza), neoliberalizm tworzy pole dla recydywy tożsamości jako jedynej dostępnej wykluczonym podstawy społecznej przynależności. Zdeklasowane rzesze pracowników, pozbawione zatrudnienia i wyzute z godności, zmuszone są dziś szukać oparcia w przedpolitycznych wspólnotach. W warunkach narzuconych przez polityki neoliberalne ich dążenia, walki i aspiracje siła rzeczy 
ulegaja fundamentalnym przekształceniom. Zamiast kwestii uniwersalnych na pierwszy plan wysuwają się problemy integracji mniejszości, które zakładają nienaruszalność panującego porządku.

Polityczne konsekwencje takiego stanu rzeczy są oczywiste. Po pierwsze, pojawia się fałszywa konkurencja między prawami mniejszości i większości. Kwestie dotyczące całego społeczeństwa, takie jak prawa pracownicze i społeczne, prawa człowieka czy nierówności ekonomiczne, zostaja zastapione rewindykacjami partykularnych przywilejów. Po drugie, w miejsce osłabionych, a czasem rozbitych policyjnymi represjami związków zawodowych iinnych form podmiotowości politycznej klas ludowych oraz porzucającego swe funkcje społeczne państwa - moga wkroczyć NGO-sy. Sektor pozarządowy oferuje substytut zaangażowania politycznego swoim pracownikom oraz substytut państwa i organizacji społecznych swoim beneficjantom (Załęski 2012; Choudry i Kapoor 2013). Zamiast wzywać do zmian politycznych, łata dziury w istniejącym układzie. Pochyla się nad potrzebującymi, ale tylko tak długo, jak trwa projekt, a w dodatku dobierając ich wedle zupełnie arbitralnych kryteriów. W ramach logiki pozarządowej politykę społeczną zastępuje dialog międzykulturowy, a uznanie dla różnorodności pełni rolę substytutu utraconej równości, kapitału społecznego i poczucia obywatelskiego sprawstwa.

Konkurencja o uznanie stanowi kulturowe dopełnienie konkurencji ekonomicznej, którą kapitał narzuca pracownikom. W okresach kryzysu w jej ramach pojawia się wrogość do innych wspólnot tożsamościowych, przede wszystkim mniejszościowych grup muzułmanów i imigrantów. Nastrojom takim ulega szczególnie niższa klasa średnia, która wcześniej cieszyła się z prosperity na kredyt, a obecnie znalazła się w gorszej sytuacji materialnej, co sprawia, że rozczarowuje się ona liberalnymi ideałami. Agresywna islamofobia staje się formą reakcji tej grupy na rosnąca niepewność i destabilizację postępującą wraz z przeciagającymi się problemami ekonomicznymi. Rozbicie solidarności klasowej, konkurencja i lęk o przyszłość tworzą też warunki, w których część klas ludowych ulega wpływom skrajnej prawicy i zamiast identyfikować przeciwnika po stronie kapitału, widzi go w innych, mniejszościowych segmentach ludu. W reakcji na to zjawisko grupy stygmatyzowane, ze względu na swoje pochodzenie i mniejszościowy status, także szukają schronienia w tożsamości. Nie mogąc liczyć na pracę, awans społeczny ani na wsparcie państwa, młodzi mieszkańcy dzielnic robotniczych znajduja je w meczetach i organizacjach charytatywnych finansowanych z budżetów Arabii Saudyjskiej i monarchii znad Zatoki. Polityki neoliberalne generuja warunki do rozwoju nie tylko antymuzułmańskiej ksenofobii, ale także islamskiego radykalizmu i dżihadyzmu. 


\section{Ksenofobiczna reakcja na kryzys i rozpad UE}

Z jednej strony, wzniecanie wrogości do obcego-imigranta z krajów arabsko-muzułmańskich okazało się poręcznym narzędziem pacyfikowania oporu i odwracania uwagi od kwestii ekonomicznych. Z drugiej, narzucenie zbuntowanym sektorom klas ludowych tożsamości islamskiej pozwala skupić na niej gniew innych grup sfrustrowanych w związku ze skutkami kryzysu: niższej klasy średniej, lepiej sytuowanych pracowników. Islamofobia zaczęła narastać jako forma fałszywej świadomości pauperyzującej się klasy średniej i części klas ludowych na Zachodzie.

Wszystkie te postacie wrogości wobec mniejszości muzułmańskich, a także praktyki mające na celu wepchnięcie części pracowników w islamską tożsamość dostrzegamy podczas wciąż trwającego w Europie kryzysu. To właśnie kryzys, który rozpoczął się od krachu finansowego w latach 2007-2008, stworzył warunki dla wzniesienia się fali ksenofobii. Załamanie neoliberalnego reżimu akumulacji ujawniło jego antydemokratyczne i ksenofobiczne oblicze. Wielka depresja podtrzymywana w czasie i pogłębiana w wyniku przeciwskutecznych polityk oszczędnościowych prowadzonych przez władze Unii Europejskiej i poszczególnych jej krajów już w roku 2010 skłoniła prawicowe elity rządzące Francji i Włoch do szukania kozłów ofiarnych, by to w ich stronę skierować narastający gniew społeczny. Zarówno Nicolas Sarkozy, jak i Silvio Berlusconi bez zahamowań eksploatowali strach przed innym, obsadzając w tej roli romskich migrantów z Bałkanów, a także uchodźców z Afryki. Dla przywódców z Paryża i Rzymu nakręcanie antyimigranckiej histerii stanowiło jeden z głównych sposobów mobilizacji poparcia. Ten drugi nawiązał współpracę z libijskim dyktatorem Muammarem Kaddafim, organizując włosko-libijskie patrole wyłapujące uchodźców, którzy usiłowali przedostać się na Północ przez Morze Śródziemne (później ok. 20 tysięcy z nich przetrzymywano na libijskiej pustyni, w obozach zbudowanych za unijne pieniądze). Ale tendencja do eksploatowania retoryki ksenofobicznej pojawiła się także w Niemczech. Mało kto pamięta, że kanclerz Angela Merkel obwieściła wtedy koniec społeczeństwa wielokulturowego. Dopiero potężna fala protestów społecznych w roku 2011 i późniejsze zwycięstwa lewicy zatrzymały odgórne tendencje ksenofobiczne. Wraz z kontrofensywą neoliberalną w roku 2015 i zduszeniem oporu Grecji doszły one jednak do głosu na skalę wcześniej niespotykaną. Dziś realnie zagrażają one samej konstrukcji Unii Europejskiej.

Latem 2015 roku na liście czarnych charakterów i głównych źródeł problemów UE muzułmańscy uchodźcy szybko zastapili „leniwych Greków”. Dla europejskiego kapitału ksenofobiczna reakcja na kryzys okazała się łatwiejsza do przełknięcia niż próby socjaldemokratycznej korekty dotychczasowych polityk ekonomicznych. Takie jest rzeczywiste tło tzw. kryzysu uchodźczego. 
Latem 2015 roku Europe zalała naprawdę niebezpieczna fala. Ale nie była to fala uciekinierów z Syrii, Afganistanu czy Afryki, lecz fala moralnej paniki wokół produkowanych przez media - w ślad za neofaszystowską prawica - fantazmatów o hordach muzułmańskich najeźdźców, które usiłują zniszczyć podstawy zachodniej cywilizacji. Uległa jej szczególnie europejska klasa średnia, sfrustrowana swoją pauperyzacją odczuwaną od kilku lat, głosując masowo na Prawo i Sprawiedliwość w Polsce, UKiP w Wielkiej Brytanii, FN we Francji czy PEGIDA oraz AfD w Niemczech. W skrajnie prawicowej wersji znane z mainstreamu sugestie, że to islam stoi za przemocą widoczną w czasie zamieszek i zamachów, przechodzą w oskarżanie islamu (konkretnie uchodźców-muzułmanów) o spowodowanie kryzysu. Przyjęcie tej optyki sprawia, że sam kryzys traci swój wymiar systemowy i staje się kryzysem uchodźczym. Taki dyskurs konstruowany jest przez siły rządzące dziś w Budapeszcie, Pradze, Warszawie, Londynie, a także w Waszyngtonie. Brexit był kulminacją owej prawicowej fali. Pierwszy etap rozpadu Unii Europejskiej stał się faktem.

\section{Podsumowanie: funkcje islamofobii w neoliberalnym zarządzaniu kryzysem}

Mamy dziś do czynienia z dwoma nierozdzielnymi postaciami wrogości wobec muzułmanów. Dopiero ujęte razem - islamofobia geopolityczna i islamofobia rozwijająca się na poziomie państw narodowych tworza pewną formację ideologiczną.

Islamofobia geopolityczna rozwijająca się w miejscu dawnego antyarabizmu legitymizuje dążenia imperiów do siłowego panowania nad zasobami energetycznymi. Jako taka wpisuje się ona w strategię energetyczną opartą na prywatyzacji sektora usług publicznych oraz ekspansji konsumpcji indywidualnej. Islamofobiczny esencjalizm stawia w centrum uwagi ponadhistoryczny, abstrakcyjny fantazmat wrogiej religii, która popycha swych wyznawców do przemocy. W ten sposób delegitymizuje się antyimperializm, przekształcając rewindykację praw ludów Południa w nieuprawnione roszczenia fundamentalistyczne.

Islamofobia, którą można nazwać wewnętrzną, legitymizuje represje i kryminalizację stosowane wobec oporu klasowego w obliczu polityki cięć, restrukturyzacji, prywatyzacji i deregulacji. Jednocześnie rozbraja i odpolitycznia ona opór ludowy - czyni go nieskutecznym i niezdolnym do rozpoznania istoty polityk neoliberalnych, ich przesłanek i funkcji klasowych. Gniew klasowy zostaje zredukowany do frustracji, a ta zwraca się przeciwko mniejszościom, kreując islamskiego kozła ofiarnego. Urasowienie/utożsamościowienie klas ludowych w kategoriach kulturowych stało się narzędziem pacyfikacji oporu pracowników i przemieszczenia konfliktu klasowego na pole tożsamościowe, na którym nic nie zagraża systemowi. Skoncentrowana na tożsamościach opowieść o konflikcie społecznym odbiera wyzyskiwanym narzędzie obrony. Odbiera bowiem walor uniwersalności walkom klas ludowych i wpisuje je w droga neoliberałom perspektywę starcia partykularyzmów. W takiej 
opowieści strajkujący pracownicy walczą nie o prawa pracownicze, ale o swoje ekskluzywne przywileje.

Pogrą̇ony w długotrwałej stagnacji kapitalizm wszelkimi sposobami odpycha od siebie widmo walki klas. Jednym z najlepszych sposobów na osiagnięcie pożądanego efektu jest kreowanie strachu przed innym. Z historycznego punktu widzenia ksenofobia zawsze była sojusznikiem kapitału - i pozostaje nim obecnie. Islamofobia jako jej postać najbardziej rozpowszechniona w euroatlantyckich ośrodkach systemu surfuje po burzliwych falach kryzysu, pozwalając trwać strukturom i siłom, które do niego doprowadziły. Przeciwstawienie się jej jest potrzebą chwili, a solidarność z zagrożonymi muzułmanami i uchodźcami to pierwsza bariera, jaką należy postawić na drodze odradzającego się faszyzmu. Ale dopiero podważenie strukturalnych przesłanek islamofobii, tkwiących w jej geopolityce i ekonomii politycznej, może skutecznie podciąć jej skrzydła. 


\section{Wykaz literatury}

Alexander, Anne. 2005. Nasser (Life \& Times). London: Haus Publishers Ltd.

Amin, Samir. 2004. Zmurszały kapitalizm. Tłum. Ryszard Wojna i Zbigniew Marcin Kowalewski. Warszawa: Wydawnictwo Akademickie Dialog.

Amin, Samir. 2005. „Amerykański imperializm, Europa i Bliski Wschód”. Tłum. Przemysław Wielgosz. Lewa Nogq 17.

Amin, Samir. 2014. "From Bandung (1955) to 2014 ; Old and new challenges for the States, the Nations and the Peoples of Asia, Africa and Latin America". http://samiramin1931.blogspot.com/2014/07/from-bandung-to-today-old-andnew.html (dostęp: 03.05.2018).

Bobako, Monika. 2011. „Konstruowanie odmienności klasowej jako urasowienie. Przypadek Polski po 1989 roku”. Biblioteka Online Think Tanku Feministycznego, http://www.ekologiasztuka.pl/pdf/f0108Bobako2011.pdf (dostęp: 03.05.2018).

Bobako, Monika. 2017. Islamofobia jako technologia władzy. Studium z antropologii politycznej. Kraków: Universitas.

Bréville, Benoit. 2015. „Ksenofobia czy prolofobia?”. Tłum. Zbigniew M. Kowalewski. Le Monde diplomatique - edycja polska 108 (luty).

Choudry, Aziz i Dip Kapoor. 2013. NGOization. Complicity, Contradictions and Prospects. London: ZED Books.

Corm, Georges. 2003. Bliski Wschód w ogniu. Oblicza konfliktu 1956-2003. Tłum. Ewa Cylwik i Radosław Stryjewski. Warszawa: Wydawnictwo Akademickie Dialog.

Corm, Georges. 2007. Religia i polityka w XXI wieku. Tłum. Ewa Cylwik. Warszawa: Wydawnictwo Akademickie Dialog.

Dunn, Elizabeth. 2008. Prywatyzujac Polskę. Tłum. Przemysław Sadura. Warszawa: Krytyka Polityczna.

Fallaci, Oriana. 2001. „Duma i wściekłość”. Tłum. Jarosław Mikołajewski. Gaz̨eta Wyborcza 14 października.

Foster, John Bellamy i Robert McChesney. 2015. Kryzys bez końca. Jak kapitat monopolistycznofinansowy wywołuje stagnacje i wstrzasy od Stanów Zjednoczonych po Chiny. Tłum. Grzegorz Konat. Warszawa: Książka i Prasa.

Golub, Philip S. 2007. „Stany Zjednoczone w obliczu schyłku imperium”. Tłum. Katarzyna Bielińska. Le Monde diplomatique - edycja polska 21 (listopad).

Grandmaison, Olivier le Cour. 2005a. „Kolonizować - eksterminować”. Tłum. Andrzej Staroń. Lewa Noga 17.

Grandmaison, Olivier le Cour. 2005b. Coloniser, exterminer: sur la guerre et l'État colonial. Paris: Fayard.

Gresh, Alain. 2008. „Świt ery postamerykańskiej”. Tłum. Agata Lukomska. Le Monde dipomatique - edycja polska 34 (grudzień).

Gresh, Alain. 2014. „Dlaczego negocjacje izraelsko-palestyńskie nie mają sensu?”. Tłum. Ewa Cylwik. Le Monde diplomatique - edycja polska 100 (czerwiec). 
Halliday, Fred. 2002. Islam i mit konfrontacji. Tłum. Robert Piotrowski. Warszawa: Wydawnictwo Akademickie Dialog.

Halliday, Fred. 2009. Bliski W schód w stosunkach międzynarodowych. W ładża, polityka, ideologia. Tłum. Joanna Tengerowicz. Kraków: Wydawnictwo Uniwersytetu Jagiellońskiego.

Harvey, David. 2007. Neoliberalizm. Historia katastrofy. Tłum. Jerzy Paweł Listwan. Warszawa: Książka i Prasa.

Huntington, Samuel i Lawrence E. Harrison. 2003. Kultura ma znaczenie. Tłum. Sławomir Dymczak. Poznań: Zysk i S-ka.

Huntington, Samuel. 1997. Zderzenie cywilizacji. Tłum. Hanna Jankowska. Warszawa: Muza.

Keddie, Nikki R. 2007. Wspótczesny Iran. Źródła i konsekwencje rewolucji. Tłum. Ivonna Nowicka. Kraków: Wydawnictwo Uniwersytetu Jagiellońskiego.

Klare, Michael. 2006. Krew i ropa. Niebeapieczeństwa i konsekwencje rosnacego uzależnienia Ameryki od importowanej ropy naftowej. Tłum. Arkadiusz Czerwiński. Warszawa: Akces.

Klein, Naomi. 2005. „Globalizacja doktryny Likudu”. Tłum. Jerzy Szygiel. Lewa Nogq 17.

Kowalewski, Zbigniew Marcin. 1999. „Malcolm X czyli rewolucja na stykach czarnego nacjonalizmu i socjalizmu (cz. I)". Lewa Noga 12.

Majmurek, Jakub. 2017. „Antyislamski pakiet prawicy. Inwazja, wylęgarnia, przemoc seksualna. Raport z obserwacji mediów". OKO Press 4 lutego. https://oko.press/antyislamski-pakiet-prawicy-inwazja-wylegarnia-przemoc-seksualnaraport-obserwacji-mediow/ (dostęp: 03.05.2018).

Michaels, Walter Benn. 2007. The Trouble with Diversity: How We Learned to Love Identity and Ignore Inequality. New York: Holt Paperbacks.

Mitchell, Timothy. 2013. Carbon Democracy: Political Power in the Age of Oil. London: Verso.

Pappé, Ilan. 2013. Współczesny Bliski Wschód. Tłum. Natalia Nowak. Warszawa: Książka i Wiedza.

Pobłocki, Kacper. 2017. Kapitalizm. Historia krótkiego trwania. Warszawa: Fundacja Bęc Zmiana.

Prończuk, Monika. 2017. „Waszczykowski powtarza »przekaz dnia« PiS: uchodźcy, czyli migranci, czyli terror, a my przecież przyjmujemy Ukraińców”. OKO Press 8 września. https://oko.press/waszczykowski-powtarza-przekaz-pis-uchodzcy-czyli-migranci-czyliterror-a-przeciez-przyjmujemy-ukraincow/ (dostęp: 03.05.2018).

Rajkowska, Joanna. 2010a. „Ty Żydu, ty Arabie!”. Krytyka Polityczna 22.

Rajkowska, Joanna. 2010b. „Prze-moc”. As Salam 2/3(20/21).

Ramonet, Ignacio. 2006. „Pięć lat wojny z terroryzmem - nowa sytuacja globalna”. Tłum. Ewa Majewska. Le Monde diplomatique - edycja polska 7 (wrzesień).

Silver, Beverly. 2009. Globalny proletariat. Ruchy pracownicze i globalizacja po 1870 r. Tłum. Marcin Starnawski. Warszawa: Książka i Prasa.

Tamás, Gáspár Miklós. 2016. „Znaczenie kryzysu migracyjnego”. Tłum. Michał Rauszer. Le Monde diplomatique - edycja polska 121 (marzec). 
Urbański, Jarosław. 2014. Prekariat i nowa walka klas. Præeobrażenia współczesnej klasy pracowniczej i jej form walki. Warszawa: Książka i Prasa.

Varoufakis, Yanis. 2015. Globalny Minotaur. Tłum. Joanna Bednarek. Warszawa: PWN.

Wallerstein, Immanuel, Randall Collins, Michael Mann, Georgi Derlugian i Craig Calhoun. 2015. Czy kapitalizm ma przyszłośc? Tłum. Irena Jarosławska. Warszawa: Wydawnictwo Akademickie Dialog.

Wallerstein, Immanuel. 2004. Koniec świata jaki znamy. Tłum. Michał Bilewicz, Adam W. Jelonek i Krzysztof Tyszka. Warszawa: Scholar.

Wallerstein, Immanuel. 2007. Analiz̧a systemón-światów. Wprowadzenie. Tłum. Katarzyna Gawlicz i Marcin Starnawski. Warszawa: Wydawnictwo Akademickie Dialog.

Wielgosz, Przemysław. 2002. „Widmo islamskiej rasy”. Lewa Nogq 14.

Yilmaz, Ferruh. 2016. How Workers Became Muslim. Immigration, Culture, and Hegemonic Transformation in Europe. Ann Arbor: The University of Michigan Press.

Załęski, Stefan. 2012. Neoliberalizm i społeczeństwo obywatelskie. Toruń: Wydawnictwo Naukowe Uniwersytetu Mikołaja Kopernika. 
Przemysław Wielgosz - dziennikarz, publicysta, wydawca i aktywista. Redaktor naczelny miesięcznika Le Monde diplomatique - edycja polska oraz serii książkowych Biblioteka Le Monde diplomatique i Biblioteka Alternatyw Ekonomicznych (w których ukazało się dotychczas ok. 60 książek). Autor i współautor/redaktor kilku książek, m.in. Opium Globalizacji (Warszawa 2004), Koniec Europy jakq znamy (Warszawa 2013), TTIP - pułapka transatlantycka (Warszawa 2015), Realny kapitalizm (Warszawa 2018), Atlas Planetarnej Pržemocy (Warszawa 2018). Współkurator wystawy Uchodícy. obecni/nieobecni (galeria Księgarnia/Wystawa Fundacji Razem Pamoja, Kraków 2016), kurator programu Przeciw-praca w ramach Atlasu Planetarnej Przemocy Biennale Warszawa i Departamentu Obecności MSN (Warszawa 2018). Publikowal m.in. w Wiadomościach Kulturalnych, Przekroju, Przegladzie, Rzeczpospolitej, Tygodniku Powszechnym, Drienniku Opinii, Aspen Review, Freitagu, Guardianie.

\section{DANE ADRESOWE:}

Przemysław Wielgosz

\section{Le Monde diplomatique - edycja polska}

Twarda 60

00-818 Warszawa

EMAIL: przemgosz@wp.pl

CYTOWANIE: Wielgosz, Przemysław. 2017. „Od walki klas do zderzenia cywilizacji. Geopolityka i ekonomia polityczna islamofobii.” Praktyka Teoretyczna 4(26): 38-61.

DOI: $10.14746 /$ prt.2017.4.2

\section{AUTHOR: Przemysław Wielgosz}

TITLE: From Class Struggle to the Clash of Civilizations: Geopolitics and the Political Economy of Islamophobia

ABSTRACT: This article attempts to outline the economic and political framework as well as the historical formation of contemporary Islamophobia. The author shows that it took place at two levels, geopolitical and internal. This process is part of the crisis of Western hegemony within the global capitalist system, and the structural economic crisis of capitalism. Islamophobia turns out to be a functional crisis management tool. First, it is an element that legitimizes imperialist policy, creating the image of a new enemy of the West. Second, it is an instrument of the neoliberal "divide and rule" policy designed to subordinate certain classes in Europe and North America.

KEYWORDS: Islamophobia, political economy, imperialism, class struggle, Islamic revolution, the Middle East, neoliberalism 